\title{
The effect of the online flipped classroom on self-directed learning readiness and metacognitive awareness in nursing students during the COVID-19 pandemic
}

\author{
Safoura Khodaei ${ }^{1}$, Shirin Hasanvand ${ }^{2 *}$, Mohammad Gholami ${ }^{2}$, Yaser Mokhayeri ${ }^{3}$ and Mitra Amini ${ }^{4}$
}

\begin{abstract}
Background: The COVID-19 pandemic has initiated digital developments in higher education while closing inperson university classes. As this crisis continues, the need to revive virtual learning opportunities was seriously felt. The present study was conducted to determine the online flipped classroom's effect on nursing students' selfdirected learning readiness and metacognitive awareness.

Methods: This quasi-experimental single-group study with pretest-posttest design recruited 34 sophomore students of a nursing school in Lorestan province, Western Iran selected by census according to the inclusion criteria. Online asynchronous learning and online flipped classrooms were used during the semester's first and second eight weeks, respectively. Students filled out self-directed learning readiness scale and metacognitive awareness inventory online before, in the middle of, and at the end of the semester. Data were analyzed using paired t-test in Stata-14 software.
\end{abstract}

Results: There was no significant difference between the mean score of metacognitive awareness before and after Online asynchronous learning $(P=0.15)$, but the mean score of self-directed learning readiness increased significantly after OA ( $\mathrm{P}=0.0004)$. After applying online flipped classrooms, students' mean (SD) scores of metacognitive awareness and self-directed learning readiness were 272.03 (53.03) and 162.03 (21.77), respectively, which confirmed their significant improvement compared to before the intervention. A comparison of the mean score changes of both methods indicated that their implementation did not lead to significant differences between the mean total score of metacognitive awareness $(P=0.15)$ and the mean total score of self-directed learning readiness ( $P=0.07)$.

Discussion: Online flipped classroom approach can be used as an effective method in nursing education by improving self-directed learning and metacognitive awareness, which are essential in online education for nursing students.

Keywords: Flipped classroom, Online learning, Self-directed learning, Metacognitive awareness, Nursing students, COVID-19, Learning Management System

\footnotetext{
* Correspondence: hasanvand.sh1390@gmail.com; hasanvand.sh@lums.ac.ir

${ }^{2}$ School of Nursing and Midwifery, Lorestan University of Medical Sciences, Khorramabad, Iran

Full list of author information is available at the end of the article
}

(c) The Author(s). 2022 Open Access This article is licensed under a Creative Commons Attribution 4.0 International License, which permits use, sharing, adaptation, distribution and reproduction in any medium or format, as long as you give appropriate credit to the original author(s) and the source, provide a link to the Creative Commons licence, and indicate if changes were made. The images or other third party material in this article are included in the article's Creative Commons licence, unless indicated otherwise in a credit line to the material. If material is not included in the article's Creative Commons licence and your intended use is not permitted by statutory regulation or exceeds the permitted use, you will need to obtain permission directly from the copyright holder. To view a copy of this licence, visit http://creativecommons.org/licenses/by/4.0/ The Creative Commons Public Domain Dedication waiver (http://creativecommons.org/publicdomain/zero/1.0/) applies to the data made available in this article, unless otherwise stated in a credit line to the data. 


\section{Background}

The COVID-19 pandemic has initiated digital developments in higher education and closed in-person classes in universities and schools [1-3]. The continued crisis raised the need to revitalize virtual learning opportunities. UNESCO recommended using distance learning and training programs and open access platforms to reduce learning process disruption [4]. Hence, online learning methods were introduced as appropriate educational strategies during the COVID-19 pandemic [1]. Such a sudden shift in educational approach from traditional to online learning without sufficient opportunity to prepare and design virtual classes created some challenges $[1,5]$. Many teachers and students were accustomed to physical classes, while all theoretical classes became online [6]. Most teachers have to make rapid advances in information technology literacy as online learning managers and use new teaching methods to increase learners' willingness [7]. Distance education also requires independent students, i.e., self-motivated learners [8]. Attitude and motivation are considered the main predictors of the desire to continue education for any type of technology-based education [9]. According to a study, online learning requires sufficient mental, physical, and economic readiness to support students' learning defects [10] especially, when some students' access to the Internet is poor, they need to be empowered to engage in active self-disciplined, and self-directed learning [11].

Hence, self-directed learning is an essential dimension [12]. Self-directed learners are empowered to decide the information they want to master [13]. Furthermore, metacognitive skills are the first critical components of the skills needed for self-directed learning [10]. In other words, there is a connection between self-directed learning and metacognition [14]. A study has pointed out a positive and significant relationship between metacognitive skills and self-directed learning. Metacognition is an essential part of the learning process defined as awareness and control of learning with two components of cognition, i.e. awareness and regulation of thinking and metacognition regulation or the management of the thinking process $[15,16]$.

It appears that computer-based educational environments and problem-based learning increase metacognition and self-direction, and the blended approach of flipped classroom model motivates students for selfdirected learning and promotes their metacognitive awareness [13, 17]. The effect of flipped classrooms as an active blended educational method on promoting self-directed learning and metacognition has been approved in several studies [18-20].

The online flipped classrooms(OFC) model, a pedagogical approach [21], is among the most popular educational methods during the COVID-19 epidemic and a promising alternative for teaching theoretical courses [22]. In traditional flipped classrooms, learners are persuaded to view video lectures at home and prepare for joint meetings. However, unlike the original flipped classroom model, learners and instructors do not meet physically but online [21]. Using social media platforms for counseling in parallel with the flipped online classroom in this unexpected crisis is critical [23]. As a widely recognized, effective, innovative, and significant strategy in the higher education of different countries, the OFC model has recently been recognized as an active educational approach in various fields because researchers and teachers have shown interest in this strategy [24-26].

Flipped classrooms increase the flexibility of teaching and change the role of teachers and learners [27]. Learners' role is shifted from inactive to active, and instructors' roles change from leader to supporter and mentor [28]. Learners also have more opportunities to participate and interact with instructors due to broader access to resources [29]. A systematic review by Tan et al. (2017) showed that this strategy helps learners improve knowledge, skills, self-learning, learning satisfaction, critical thinking, and problem-solving skills [28]. Online learning can cover a range of applications, systems such as computer-based learning and web-based learning. One of the computer applications to learning is the Learning Management Systems (LMS) [30], and it is often used to prepare a flipped classroom [31].

Given the need to support learners' participation and strengthen their self-directed learning skills, especially in distance education [32], the lack of an effective teaching method during the COVID-19 pandemic, and insufficiency of studies on the effectiveness of various online education methods, including flipped classroom, especially online courses during the COVID-19 pandemic [6, 21 ], and the supportive role of social media, the present study was conducted to determine the effect of the flipped classroom along with online teaching on selfdirected learning and metacognitive awareness of nursing students. Previous studies focused on online asynchronous (OA) Learning (which allows learners to watch instructional materials at any time they want and does not include a live video lecture) rather than a combination of online learning methods, which remains a controversial question [21].

\section{Methods \\ Study design}

This study was a quasi-experimental single-group pretest-posttest study using intragroup comparison. Since only one group of students is admitted each 
semester, a group of undergraduate students was selected as both the control group and the intervention group.

\section{Participants and setting}

This study recruited 34 nursing students at Khorramabad School of Nursing and Midwifery, affiliated with Lorestan University of Medical Sciences in Western Iran. The theoretical course of Adults and Older Adults Nursing II on Respiratory, Cardiovascular, and Kidney Disorders were presented in the first semester of the 20202021 academic year, simultaneously with the outbreak of the COVID-19 pandemic, and the practical part of the course was presented one semester later. Hence, students did not have the experience of dealing with such cases and clinical care for them. Simultaneously with this course, other courses were mainly held asynchronously (mainly in PDF and podcast files) via LMS.

Nursing students were selected via convenience sampling for this study based on the inclusion criteria of enrollment in the theoretical course of Adults and Older Adults Nursing II and studying in the second year of nursing. Unwilling students and those with previous flipped classroom experience or other self-directed methods were excluded from the study. Since there was no other group of students simultaneously studying with the case group, the participants were considered both the control and intervention groups. The first eight weeks were held, with 34 students receiving OA training as the control group. The same 34 students continued the course online without face-to-face sessions as the OFC group for eight weeks. Finally, the participants were compared with themselves.

\section{Tools}

Data were collected using a socio-demographic information checklist (including age, gender, place of residence, marital status, and active learning experience such as a flipped classroom), the Self-Directed Learning Readiness Scale for Nursing Education (SDLRSNE), and the Metacognitive Awareness Inventory (MAI).

Fisher developed SDLRSNE in Australia in 2001 specifically for nursing [33] with 40 items and three dimensions of self-management (items 1 to 13), desire for learning (items 14 to 25), and self-control (items 26 to 40). Items are scored based on a 5-point Likert scale from strongly disagree $(=1)$ to strongly agree $(=5)$, and the mean total score ranges between 40 and 200 [34]. Four items are scored inversely. A mean score above 150 indicates self-directed learning readiness [35]. The psychometric evaluation of SDLRSNE in Iran reported the Cronbach's alpha coefficient of 0.82 for the whole scale and 0.60-0.78 for its subscales [36]. In the present study, Cronbach's alpha for the whole scale and the subscales of self-management, desire for learning, and self-control were $0.94,0.88,0.87$, and 0.88 , respectively.

The following tool was MAI, consisting of 52 items to evaluate the various dimensions of metacognition. Participants respond to each item based on a 7-point Likert scale from strongly agree $(=1)$ to strongly disagree $(=7)$. Its maximum score is 364 , and its minimum score is 52 [37]. This tool has already been translated into Persian and psychometric by Kooshki and Shavandi (2019) in Iran. The reliability of the instrument was confirmed by the internal consistency method with Cronbach's alpha 0.82 . In order to evaluate the construct validity, exploratory factor analysis was used. After confirmatory factor analysis, the instrument showed an acceptable fit [38].

\section{Measuring variables}

The link to the data collection tool was sent to the students via WhatsApp ${ }^{\mathrm{TM}}$ messenger to observe social distancing and avoid in-person classes in three stages: before uploading the content of the first session and one week before the first lecture (pre-test), at the end of week 8 (post-test 1), and the end of week 16 (post-test 2 ), and they were asked to complete and submit the tool within a maximum of one week. Before sending the link, the students were briefed on how to complete the tool via the WhatsApp ${ }^{\text {TM }}$ channel. The instructions for completing the tool incorporated with the online tool also clearly stated how to complete the tool.

\section{Intervention}

The study began after obtaining permission from the Research and Technology Deputy of Lorestan University of Medical Sciences and coordination with professors. One week before the first lecture, the study tools were completed by the participants. The professors presented the Adult and Older Adults Nursing II course in 16 twohour sessions, including renal and cardiovascular diseases nursing, divided into two 8-session parts. Eight sessions on renal diseases were presented during the first eight weeks. Eight sessions related to cardiovascular diseases were presented with OFC from mid-semester to the end of week 16 (Table 1).

All the participating students were briefed regarding the outline, general and specific objectives, and titles and number of sessions of the course, students' assignments during the course, OFC teaching method, class time (a two-hour module per week), and evaluation and class rules in online sessions in a 90-minute session. They were also uploaded in the references section and the Course Introduction to the local LMS (special software for university learning) to be permanently accessible to the learners who wanted to review the course schedule. 
Table 1 Titles of online learning modules for the adults and older adults nursing II course

\begin{tabular}{|c|c|c|}
\hline $\begin{array}{l}\text { Sessions } \\
\text { groups }\end{array}$ & OA educational content & OFC educational content \\
\hline Module 1 & $\begin{array}{l}\text { Evaluation of kidney and urinary tract diseases and nursing care in } \\
\text { diagnostic tests }\end{array}$ & Management of patients with chronic heart failure \\
\hline Module 2 & Prevention and management of kidney and urinary tract infections & $\begin{array}{l}\text { Management of patients with coronary artery disease (angina } \\
\text { pectoris) }\end{array}$ \\
\hline Module 3 & Prevention and management of urinary tract stones & $\begin{array}{l}\text { Management of patients with coronary artery disease (myocardial } \\
\text { infarction) }\end{array}$ \\
\hline Module 4 & $\begin{array}{l}\text { Nursing care in renal parenchymal diseases (e.g., nephrotic } \\
\text { syndrome) }\end{array}$ & $\begin{array}{l}\text { Structural, infectious and inflammatory disorders of the heart } \\
\text { (cardiomyopathies) }\end{array}$ \\
\hline Module 5 & Vital care in surgery and trauma to the kidneys and urinary tract & $\begin{array}{l}\text { Structural, infectious and inflammatory disorders of the heart } \\
\text { (valvular disorders) }\end{array}$ \\
\hline Module 6 & $\begin{array}{l}\text { Reproductive health and management of infectious diseases of } \\
\text { the female reproductive system }\end{array}$ & $\begin{array}{l}\text { Structural, infectious and inflammatory disorders of the heart } \\
\text { (infectious heart diseases) }\end{array}$ \\
\hline Module 7 & $\begin{array}{l}\text { Reproductive health and management of infectious diseases of } \\
\text { the male reproductive system }\end{array}$ & Evaluation and care of patients with hypertension \\
\hline Module 8 & Nursing care in male and female genital malignancies & $\begin{array}{l}\text { Evaluation and management of patients with vascular disorders } \\
\text { and peripheral circulatory problems }\end{array}$ \\
\hline
\end{tabular}

\section{Teaching methods in the flipped classroom}

At the end of the eighth session, the link to the data collection tools was sent to the students' mobile phones via WhatsApp ${ }^{\text {tw }}$ so that they could complete the tools. From the ninth session onward, eight modules on cardiovascular disease management were presented following OFC principles, including a three-step process (pre-class, inclass, and post-class activities), described in detail below.

\section{Pre-class activities}

At the self-learning stage, video or textual contents designed by the instructor were presented outside the official classroom time. To this end, one week before each module was presented, its educational content was made available to the participants in narrated PowerPoint files, podcasts, or short educational videos. One of the instructors, the second author, produced the 20- to 30minute electronic content by content development standards and with the help of Storyline software. Evidencebased tips by Persky et al. (2017) were also used in designing the content (video or reading material) [39]. Each content included a topic, general and specific objectives, text, summary, and a self-assessment. The online learning platform for content sharing was the interactive LMS of Iran Virtual University of Medical Sciences, accessible at "https://lumsnavid.vums.ac.ir". These software systems deal with the application, registration, management, follow-up, evaluation, presentation of programs, interactions between learners and program content, and interactions between learners and professors. The content uploaded on this system can be easily viewed through students' laptops, computers, or mobile phones. Students had access to the content, assignments, self-assessments, discussions, and messages through the platform. Due to the user-friendliness of this platform and students' experience with it, they knew how to use it. In addition, instructions were available in both video and PDF formats on the platform.

One educational module was accessible to students each week to analyze. Students were asked to carefully and individually read the contents for independent thinking and reflect on them. After the individual study, some students were selected in a maximum of 2-3 groups of 6 individuals each week to do group homework. One student was selected as the coordinator of each group. We tried to have a balanced combination of strong and weak students in each group. At this stage, one of the active learning strategies, such as reflection paper, concept map, and Cornell notes, was used by groups in each session to summarize the content and report group activities. As a pre-assessment, students were asked to discuss a few critical questions about each content one week before the start of the class, focusing on their knowledge, ambiguities, challenges, and previous experiences on the topic in the LMS Discussion Forum.

Moreover, a WhatsApp group was formed to reduce student stress. Teachers were also added to the group. When the need arose and in the case of questions, the teachers answered the questions and monitored outclass discussions. There were also discussions about the content uploaded in LMS and related assignments between students on this channel. All the coordination required for each session was already given in WhatsApp.

\section{In-class activities}

This stage, also known as a dialogue with others, focused on peer-to-peer activities and the online discussion of teachers with students, which lasted about $90 \mathrm{~min}$. After 
seeing the required training materials, students attended online classes through the Adobe Connect platform at the time specified in the class schedule. At this stage, students spend their time on activities such as problemsolving or discussion with peers. Most students were randomly asked about the subject for a basic learning assessment during this stage, and in-class quizzes were given. Students' responses were also reviewed and criticized by their peers in the form of a mini-review. Students could share their comments by typing in the chat box or activating the microphone and speaking. They could answer the quizzes via Google Docs ${ }^{\mathrm{mm}}$. These activities provided an opportunity to assess and identify students' learning difficulties.

Furthermore, during the class, the coordinator of each group prepared a summary of the content of each session as an audio file of $5 \mathrm{~min}$, text, or both at a predetermined time and shared it in the discussion forum after the students agreed. Other students read the summary and submitted their comments. After presenting the students' comments, the first author (TA) had to review the comments on a daily and continuous basis and encourage the students to participate as much as possible. At the end of the class, the instructor corrected the students' misconceptions, provided feedback, and summarized and highlighted essential points related to the content or patient care in the form of microteaching. Students were informed that unlike the initial online class quiz, which did not affect the final evaluation, active participation in the discussion forum and the number of posts (after a qualitative review, of course) impacted the final grade.

\section{Post-class activities}

Extended assignments (descriptive and problem-based) were presented after completing each educational content and entering the following to consolidate learning. Assignments were uploaded in the assignments section of LMS and reviewed by the second author, who provided feedback within a set deadline (about two weeks).

\section{Learning assessment}

Three instructors made the assessment. The tests related to the assessment of essential learning did not have any impact on the final assessment score, while the students' discussions in the forum and individual and group assignments were considered. Hence, the final evaluation was based on the final exam consisting of multiple-choice questions (40\%), group summarization of the content (20\%), participation in the discussion forum and online classes (20\%), and final projects $(20 \%)$.

\section{Teaching methods in the control group}

Education was provided as OA for eight consecutive sessions per week. The content of lessons was uploaded in LMS in narrated PowerPoint ${ }^{\mathrm{Tw}}$ files and podcasts according to the course schedule and its chronological order. Students experienced self-learning by relying on the uploaded content.

\section{Data analysis}

Data were analyzed using Stata-14 software. Descriptive statistics including frequency, percentage, mean and standard deviation were used. Paired t-test was used to compare the mean scores of metacognitive awareness and self-directed learning in the pre-and post-test stages and comparison of the two methods.

\section{Results}

Thirty-four nursing students, including 20 males (59\%) and 14 females (41\%), participated in this study. Twentyfour $(71 \%)$ of them were local (living in Lorestan province). Their mean age was $22(\mathrm{SD}=1)$, and only $2(6 \%)$ of them were married. None of them had the experience of attending flipped classrooms (in person or online).

There was no significant difference between the mean scores of metacognitive awareness $(p=0.15)$ before and after implementing the offline method. However, there was a significant difference between the mean score of self-directed learning readiness $(p=0.0004)$ before and after implementing the OA method, which indicated an increase. The mean scores of desire for learning ( $P$ value $=0.01)$ and self-control $(P$-value $=0.02)$ increased significantly after the OA method (Table 2).

After applying OFC, students' mean metacognitive awareness and self-directed learning scores confirmed their significant improvement before the intervention. After applying OFC, the mean scores of self-directed learning subscales, including self-management, desire for learning, and self-control, confirmed the significant improvement of the variables compared to before the intervention (Table 3).

According to Table 4, the comparison of the mean score changes of both methods indicated a lack of a significant difference between the mean total score of metacognitive awareness $(P$-value $=0.15)$ and the mean total score of self-directed learning $(P$-value $=0.07)$ after the implementation of the OFC and OA methods. Furthermore, the comparison of changes in the mean score of variables between the two methods showed a significant increase in the mean total score of selfmanagement $(P$-value $=0.02)$, while there was no significant difference in the mean total score of desire for learning $(P$-value $=0.52)$ and self-control $(P$-value $=0.28)$. 
Table 2 Mean score of metacognitive knowledge and self-directed learning of nursing students in the OA method

\begin{tabular}{|c|c|c|c|c|}
\hline & \multirow{3}{*}{$\begin{array}{l}\text { Total number=34 } \\
\text { Pre-test } \\
\text { Mean (SD) }\end{array}$} & \multicolumn{3}{|c|}{ Total number=34 } \\
\hline & & \multirow{2}{*}{$\begin{array}{l}\text { Post-test } \\
\text { Mean (SD) }\end{array}$} & \multicolumn{2}{|c|}{ Paired $t$-test of the participants } \\
\hline & & & $\mathrm{T}$ & $P$-value \\
\hline Total score of metacognitive awareness & $255.68(53)$ & $262.68(48.16)$ & 1.46 & 0.15 \\
\hline Total score of self-directed learning & $148.76(23.06)$ & $155.82(20.6)$ & 3.96 & $<0.001$ \\
\hline Self-management & $45.5(8.19)$ & $46.44(9.1)$ & 0.76 & 0.45 \\
\hline Desire for learning & $45.76(7.1)$ & $48.18(6.74)$ & 2.49 & 0.01 \\
\hline Self-control & $58.32(8.89)$ & $61.03(8.12)$ & 2.5 & 0.02 \\
\hline
\end{tabular}

\section{Discussion}

The present study showed that the mean total score of self-directed learning readiness increased after using both methods (OA and OFC), and as a result, they positively affected students' desire for learning and selfcontrol, but there was no significant difference between the two groups. Among the self-directed learning subscales, the mean score of the self-management variable increased in the OFC method.

Evidence suggests that synchronous and asynchronous activities are both critical and complementary because a synchronous approach increases learners' incentive and attention, and an asynchronous approach increases data processing ability [21]. Some sources refer to the asynchronous method as self-paced learning, which leads the learner to self-direction [40]. It occurs when learners perform learning activities in proportion to their speed by having the right to choose the task time [13]. Traditional online courses increase flexibility by focusing on asynchronous tasks [21]. The OA method also showed positive results for the self-directed variable could be attributed to learners' high motivation. In the absence of instructors and classmates in the OA method, being motivated is the main incentive whose absence will make students' involvement with the subject and learning more difficult.

On the other hand, OFC based on an LMS also positively affected learners' readiness for self-directed learning. According to Ugwoke (2018), flipped classrooms via online tools can develop students' interest in learning and meet learners' needs. In the flipped classroom using LMS, students can freely choose the most proper ways to obtain new knowledge [41]. Learners can develop self-directed and self-paced learning skills by studying the content prepared by the teacher asynchronously before starting the class. Self-management skills can be developed using the content along with the teacher's supervision [13]. Before entering the flipped classroom, mastery of the content increases learners' intuitive learning skills and confidence to perform classroom activities [42]. Studies have also shown that flipped classrooms improve learners' self-directed learning readiness and increase their satisfaction [18]. There is evidence suggesting that the flipped classroom approach positively affects learners' motivation and significantly improves selfdirected readiness skills $[18,20,43]$. Stoher et al. (2020) compared the effect of OFC with campus-based courses and reported no difference in the average performance between the two groups. In their study, OFC was compared with campus-based courses [21]. Also, postgraduate students participated in their study. There is emerging evidence that age and previous education may positively affect self-directed learning readiness [33].

One of the internal factors affecting self-directed learning is the readiness to accept the responsibility of learning, and that constitutes the two main characteristics of the flipped classroom and autonomy [44]. Furthermore, self-directed learning readiness is like a cycle in the learning process that requires prior readiness and motivation to enter this cycle [45]. Students were well

Table 3 Mean score of metacognitive knowledge and self-directed learning of nursing students in the OFC method

\begin{tabular}{|c|c|c|c|c|}
\hline & \multirow{3}{*}{$\begin{array}{l}\text { Total number=34 } \\
\text { Pre-test } \\
\text { Mean (SD) }\end{array}$} & \multicolumn{3}{|c|}{ Total number=34 } \\
\hline & & \multirow{2}{*}{$\begin{array}{l}\text { Post-test } \\
\text { Mean (SD) }\end{array}$} & \multicolumn{2}{|c|}{ Paired t-test of subjects } \\
\hline & & & $\bar{T}$ & $P$-value \\
\hline Total score of metacognitive awareness & $255.68(53)$ & $272.03(50.03)$ & 2.29 & 0.03 \\
\hline Total score of self-directed learning & $148.76(23.06)$ & $162.03(21.77)$ & 3.70 & $<0.001$ \\
\hline Self-management & $45.5(8.19)$ & $50.56(9.48)$ & 4.48 & $\leq 0.0001$ \\
\hline Desire for learning & $45.76(7.1)$ & $48.94(7.59)$ & 2.42 & 0.02 \\
\hline Self-control & $58.32(8.89)$ & $62.5(7.66)$ & 2.96 & $<0.01$ \\
\hline
\end{tabular}


Table 4 A Comparison of the mean scores of metacognitive knowledge and self-directed learning of students between the two methods

\begin{tabular}{|c|c|c|c|c|}
\hline & \multirow{3}{*}{$\begin{array}{l}\text { Total number=34 } \\
\text { OA method } \\
\text { Mean (SD) }\end{array}$} & \multicolumn{3}{|c|}{ Total number $=34$} \\
\hline & & \multirow{2}{*}{$\begin{array}{l}\text { OFC method } \\
\text { Mean (SD) }\end{array}$} & \multicolumn{2}{|c|}{ Paired t-test of subjects } \\
\hline & & & $\bar{t}$ & $P$-value \\
\hline Total score of metacognitive awareness & $262.68(48.16)$ & $272.03(50.03)$ & -1.49 & 0.15 \\
\hline The total score of self-directed learning & 155.82(20.6) & $162.03(21.77)$ & -1.88 & 0.07 \\
\hline Self-management & $46.44(9.1)$ & $50.56(9.48)$ & -2.36 & 0.02 \\
\hline Desire for learning & $48.18(6.74)$ & $48.94(7.59)$ & -0.66 & 0.52 \\
\hline Self-control & $61.03(8.12)$ & $62.5(7.66)$ & -1.1 & 0.28 \\
\hline
\end{tabular}

prepared given the average score of learners' selfdirected learning readiness before the intervention. Another possible explanation is that the teachers of the studied faculty (including the second and third authors) had used new and active educational methods, particularly e-learning and blended education, to teach their students for many years, including the participants in this study, and that they had positive experiences in teaching the same students with a blended method from the previous semester. Students' previous experience using e-learning and blended learning gave them high self-confidence to take responsibility for their learning and thus achieve good self-direction readiness. Zamnah (2019) et al. showed that learning self-direction increases students' self-confidence [46].

An essential feature of self-directed learners is that they make good use of online learning environments [47], and at the same time, scaffolding should be considered, as seen in this study and following the methods mentioned above. Robinson et al. (2020) believe that the development of self-directed learning requires a scaffolding approach such that teacher-centered activities help learners achieve more self-regulation in self-direction, for which flipped classroom is suggested [13]. In the self-directed learning process, learners set goals, evaluate their progress, structure activities over time, identify resources, and seek feedback [13]. The body of evidence also suggests that self-directed learning readiness in online environments leads to better academic performance and learners' success. In particular, online environments provide learners with the right to choose how to learn to strengthen self-directed readiness [48].

LMS promotes teaching and learning as a portal to innovative technology and provides forum discussion and several interactive features [49]. Adind et al. (2020) stated that discussion forums allow learners to interact, encounter, and actively process problems. Therefore, it promotes their learning, which they believe results from the development of students' self-directed learning [48]. Moreover, in a well-designed SDL environment, motivation, a sense of control, self-confidence, and self-belief increase [13]. The results of the present study results showed that OFC had improved self-management in learners compared to the OA method. Self-management is vital in self-directed learning, and learners should choose different strategies to deal with challenges [50].

The results of the present study also indicated that the OFC method promotes the metacognitive awareness of learners. There is a growing body of evidence to suggest that the OFC method promotes the metacognitive awareness of learners $[19,51,52]$.

Chan et al. (2021) conducted a similar study to determine the effectiveness of active learning (blended flipped classrooms and enhanced lectures) on the improvement of the metacognitive awareness of students, the results of which were consistent with the present study. According to the authors, flipped classrooms make students take responsibility for their learning. As a result, they will have more flexibility to learn. [53]. Metacognitive awareness and independence in learning are among the skills necessary for distance learning, which require much time to acquire and cannot be quickly learned through distance learning methods [54]. Also, independence in learning requires achieving metacognitive awareness. Metacognitive skills such as metacognitive awareness control and regulate cognitive processes through independence in learning and self-direction [55]. In this study, according to students' long-term distance learning experiences in previous semesters, metacognitive awareness improved with OFC despite the short intervention time. According to Bektas (2020), metacognitive awareness increases students' selfconfidence and motivation, such that increasing selfconfidence will help them learn with their advanced mechanisms and use appropriate opportunities to access resources and information. Eventually, they achieve higher metacognitive awareness $[56,57]$. In the present study, the mean total score of students' metacognitive awareness before the intervention increased their selfconfidence and motivation. Siqueira (2020) also reported a positive relationship between metacognitive skills and motivation in those active methods such as flipped classrooms could motivate and ultimately develop metacognitive skills [45]. 
Furthermore, metacognitive skills are part of selfdirected learning [57]. Ultimately, self-directed learning in active approaches such as flipped classroom develops metacognitive skills, including metacognitive awareness [53]. Mukaddes Örs et al. found a positive and significant correlation between self-directed learning in nursing students [57].

Moreover, in this study, we tried to use WhatsApp in parallel with LMS to strengthen the OFC. Arifani et al. (2020) realized that this strategy could be an excellent way to promote the cohesive ability of English learners [58]. One of the most favorite applications is WhatsApp and learners should be encouraged to integrate informal learning activities to support and increase formal learning [59]. During the Covid-19 outbreak, online learning environments became critical, particularly teacherstudent interaction in these contexts [60]. The teaching method was suddenly changed to a completely online method due to the COVID-19 epidemic. Because we did not have access to the students for face-to-face communication, they were not sufficiently prepared for the intervention. However, before the intervention, the students were briefed regarding their duties and expectations using WhatsApp ${ }^{\text {tw }}$ messenger to prepare them for the interventions.

Our study had some limitations. It was a quasiexperimental and single-group study. At our university, only one group is accepted each semester. Also, the sample size was small. It is recommended that further studies with a larger sample size be performed as a clinical trials with a longer course in the future.

\section{Conclusions}

With the increasing growth of online learning during the COVID-19 pandemic and the effectiveness of the flipped classroom as a novel method, this study was conducted to determine the effectiveness of OFC on selfdirected learning readiness and metacognitive awareness of nursing students. The results of the present study results showed the effectiveness of LMS-based online learning methods on students' self-directed learning readiness and metacognitive awareness. Students had good self-direction and metacognitive knowledge before the intervention and had the experience of learning with distance and hybrid teaching methods. This background, combined with the active educational approach used, yielded satisfactory results despite the short duration of the intervention. Hence, further studies with more extended periods are recommended to examine the effect of OFC on self-directed learning and other related variables.

\section{Abbreviations}

OFC: Online flipped classrooms; LMS: Learning Management Systems; OA: Online asynchronous; SDLRSNE: Self-Directed Learning Readiness Scale for Nursing Education; MAl: Metacognitive awareness inventory; TA: Teacher assistant

\section{Acknowledgements}

This study was performed as an MSc thesis. We would like to thank all the students at the School of Nursing and Midwifery, affiliated with Lorestan University of Medical Sciences students. This article was approved by the Vice-Chancellery for Research and Technology Deputy of Lorestan University of Medical Sciences (1399.040).

\section{Authors' contributions}

SH, SK, and MG were responsible for the study conception/design. SH, SK, and $M G$ performed the data collection. YM analyzed and interpreted the participants' data. S.H, S.K., M.G., YM, and MA were significant contributors in writing the manuscript. All the authors read and approved the final manuscript.

\section{Funding}

This research did not receive any specific grant from funding agencies in the public, commercial, or not-for-profit sectors.

\section{Availability of data and materials}

Data and materials are available at the request of the readers. Requests for data should be addressed to the corresponding author.

\section{Declarations}

\section{Ethics approval and consent to participate}

This study was conducted under the Declaration of Helsinki. The ethics code was obtained from the Deputy for Research and Technology of Lorestan University of Medical Sciences (IR.LUMS.REC.1399.040). The students were briefed with comprehensive and clear explanations about the research objectives. Given the role of some researchers (the second and third authors) as professors, efforts were made to protect the rights of participants. The online questionnaire contained information about the study, its objectives, the anonymity of the survey, and instructions for completing the questionnaire. All the participants were ensured of the voluntary nature of the study and confidentiality of the data. They were assured that the intervention would not affect their final evaluation score. Informed consent was obtained verbally, and the ethics committee approved it.

\section{Consent for publication}

Not applicable.

\section{Competing interests}

The authors declare that they have no competing interests.

\section{Author details}

${ }^{1}$ Student Research Center, Lorestan University of Medical Sciences, Khorramabad, Iran. ${ }^{2}$ School of Nursing and Midwifery, Lorestan University of Medical Sciences, Khorramabad, Iran. ${ }^{3}$ Cardiovascular Research Center, Shahid Rahimi Hospital, Lorestan University of Medical Sciences, Khorramabad, Iran.

${ }^{4}$ Clinical Education Research Center, Shiraz University of Medical Sciences, Shiraz, Iran.

Received: 11 September 2021 Accepted: 3 January 2022

Published online: 19 January 2022

\section{References}

1. Basilaia G, Kvavadze D. Transition to online education in schools during a SARS-CoV-2 coronavirus (COVID-19) pandemic in Georgia. Pedagogical Res. 2020;5(4):em0060. https://doi.org/10.29333/pr/7937.

2. Ahmady S, Shahbazi S, Heidari M. Transition to virtual learning during the coronavirus disease-2019 crisis in Iran: opportunity or challenge? Disaster Med Public Health Prep. 2020;14(3):e11-2. https://doi.org/10.1017/2Fdmp.2 020.142 .

3. Adedoyin OB, Soykan E. Covid-19 pandemic and online learning: the challenges and opportunities. Interact Learn Environ. 2020;1-13. https://doi. org/10.1080/10494820.2020.1813180.

4. Tabatabai S. Covid-19 impact and virtual medical education. J Adv Med Educ Pro. 2020;8(3):140-3. https://doi.org/10.30476/jamp.2020.86070.1213. 
5. Camargo CP, Tempski PZ, Busnardo FF, Martins MdA, Gemperli R. Online learning and covid-19: a meta-synthesis analysis. Clinics. 2020;75. https://doi. org/10.6061/clinics/2020/e2286

6. Yen T-FT. The performance of online teaching for flipped classroom based on COVID-19 aspect. Asian J Educ Soc Stud. 2020;57-64. https://doi.org/10. 9734/ajess/2020/v8i330229.

7. $\mathrm{Ma} \mathrm{G}$. The effectiveness of synchronous online flipped learning in college EFL reading course during the covid-19 epidemic. 2020. https://doi.org/1 0.21203/rs.3.rs-84578/v1.

8. Muslimin Al, Harintama F. Online learning during pandemic: students' motivation, challenges, and alternatives. loquen: Engl Stud J. 2020;13(2):608. https://doi.org/10.32678/loquen.v13i2.3558.

9. Panisoara IO, Lazar I, Panisoara G, Chirca R, Ursu AS. Motivation and continuance intention towards online instruction among teachers during the covid-19 pandemic: the mediating effect of burnout and technostress. Int J Environ Res Public Health. 2020;17(21). https://doi.org/10.3390/ijerph17218002.

10. Ghomi M, Moslemi Z, Mohammadi S. The relationship between metacognitive strategies with self-directed learning among students of Qom University of Medical Sciences. Educ Strategy Med Sci. 2016;9:248-59 http://edcbmj.ir/article-1-1016-en.html.

11. Zhu X, Liu J. Education in and after covid-19: immediate responses and long-term visions. Postdigital Sci Educ. 2020;2(3):695-9. https://doi.org/10.1 007/s42438-020-00126-3.

12. Kohan N, Arabshahi KS, Mojtahedzadeh R, Abbaszadeh A, Rakhshani T, Emami A. Self-directed learning barriers in a virtual environment: a qualitative study. J Adv Med Educ Prof. 2017;5(3):116-123.

13. Robinson JD, Persky AM. Developing self-directed learners. Am J Pharm Educ. 2020;84(3):847512. https://doi.org/10.5688/ajpe847512

14. Shih H-cJ, Huang S-hC, editors. The development of EFL learners' metacognition in a flipped classroom. Proceedings of the 8th Centre for Language Studies International Conference. 2018.

15. Smedley A. The self-directed learning readiness of first-year bachelor of nursing students. J Res Nurs. 2007;12(4):373-85. https://doi.org/10.1177/17449871 07077532

16. Jaleel S. A study on the metacognitive awareness of secondary school students. Univ J Educ Res. 2016:4(1):165-72. https://doi.org/10.13189/ujer.2 016.040121.

17. Limueco J, Prudente M. Flipped classroom enhances student's metacognitive awareness. 2019. p. 70-74. https://doi.org/10.1145/33 06500.3306507

18. Fan J-Y, Tseng $Y-J$, Chao L-F, Chen S-L, Jane S-W. Learning outcomes of a flipped classroom teaching approach in an adult-health nursing course: a quasi-experimental study. BMC Med Educ. 2020;20(1):1-11. https://doi.org/1 0.1186/s12909-020-02240-z

19. Limueco JM, Prudente MS, editors. Flipped classroom enhances student's metacognitive awareness. Proceedings of the 10th International Conference on E-Education, E-Business, E-Management and E-Learning. 2019. https:// doi.org/10.1145/3306500.3306507

20. Zainuddin Z, Perera CJ. Supporting students' self-directed learning in the flipped classroom through the LMS tes blend space. On the Horizon. 2018 https://doi.org/10.1108/OTH-04-2017-0016.

21. Stöhr C, Demazière C, Adawi T. The polarizing effect of the online flipped classroom. Comput Educ. 2020;147:103789. https://doi.org/10.1016/j. compedu.2019.103789

22. Guraya S. Combating the covid-19 outbreak with a technology-driven eflipped classroom model of educational transformation. J Taibah Univ Med Sci. 2020. https://doi.org/10.1016/j.jtumed.2020.07.006.

23. Tabari P, Amini M. Educational and psychological support for medical students during the covid-19 outbreak. Med Educ. 2020:1-3. https://doi. org/10.1111/medu.14376

24. Chu T-L, Wang J, Monrouxe L, Sung Y-C, Kuo C-I, Ho L-H, et al. The effects of the flipped classroom in teaching evidence-based nursing: a quasiexperimental study. Plos One. 2019;14:e0210606. https://doi.org/10.1371/ journal.pone.0210606.

25. Hannafin NM, Phillips R. The flipped classroom applied to the clinical skills lab setting. Health Commun. 2017;2(4):44. https://doi.org/10.4172/2472-1654.100084.

26. Ozdamli F, Aşıksoy G. Flipped classroom approach. World J Educ Technol. 2016:8:98. https://doi.org/10.18844/wjet.v8i2.640

27. Kozikoglu I. Analysis of the studies concerning flipped learning model: a comparative meta-synthesis study. Int J Instr. 2019;12(1):851-68. https://doi. org/10.29333/iji.2019.12155a.
28. Tan C, Yue W-G, Fu Y. Effectiveness of flipped classrooms in nursing education: systematic review and meta-analysis. Chin Nurs Res. 2017:4(4): 192-200. https://doi.org/10.1016/j.cnre.2017.10.006

29. Yildirim FS, Kiray SA. Flipped classroom model in education. Research Highlights in Education and Science. 2016. p. 2.

30. Louhab FE, Bahnasse A, Bensalah F, Khiat A, Khiat Y, Talea M. Novel approach for adaptive flipped classroom based on learning management system. Educ Inf Technol. 2020;25(2):755-73. https://doi.org/10.1007/s10639019-09994-0.

31. Yamada Y, Hirakawa M, editors. A case study of analyzing logs of LMS in flipped classroom. 2015 iiai 4th International Congress on Advanced Applied Informatics. IEEE; 2015. https://doi.org/10.1109/IIAI-AAI.2015.255.

32. Tomas L, Doyle T, Skamp K. Are first-year students ready for a flipped classroom? A case for a flipped learning continuum. Int J Educ Technol High Educ. 2019;16(1):5. https://doi.org/10.1186/s41239-019-0135-4.

33. Slater CE, Cusick A. Factors related to self-directed learning readiness of students in health professional programs: a scoping review. Nurse Educ Today. 2017;52:28-33. https://doi.org/10.1016/j.nedt.2017.02.011.

34. Shokar GS, Shokar NK, Romero CM, Bulik RJ. Self-directed learning: looking at outcomes with medical students. Fam Med Kansas City. 2002;34(3):197200.

35. Cadorin L, Bressan V, Palese A. Instruments evaluating the self-directed learning abilities among nursing students and nurses: a systematic review of psychometric properties. BMC Med Educ. 2017;17(1):1-13. https://doi. org/10.1186/s12909-017-1072-3.

36. Nadi MA, Sadjadian I. Validation of a self-directed learning readiness scale for medical and dentistry students. Iran J Med Educ. 2011;11(2):174-82 http://ijme.mui.ac.ir/article-1-1274-en.htm.

37. Vaghar Seyyedin A, Vanaki Z, Taghi S, Molazem Z. The effect of guided reciprocal peer questioning (grpq) on nursing students' critical thinking and metacognition skills. Iran J Med Educ. 2009;8(2):333-40.

38. Kooshki S, Shavandi A. Psychometric properties of metacognitive awareness inventory and its relationship with achievement goals in secondary school students in Shahriar city. Q Educ Meas. 2019;10(37):137-67. https://doi.org/1 0.22054/jem.2020.46853.1971

39. Persky AM, Mclaughlin JE. The flipped classroom-from theory to practice in health professional education. Am J Pharm Educ. 2017;81(6). https://doi. org/10.5688/ajpe816118.

40. Lalitha T, Sreeja P. Personalised self-directed learning recommendation system. Proc Comput Sci. 2020;171:583-92. https://doi.org/10.1016/j.procs.2 020.04.063.

41. Ugwoke EO, Edeh NI, Ezemma JC. Effect of flipped classroom on learning management systems and face-to-face learning environments on students' gender, interest and achievement in accounting. Library Philosophy and Practice. 2018: p. 011

42. Zainuddin Z. Students' learning performance and perceived motivation in gamified flipped-class instruction. Comput Educ. 2018;126. https://doi.org/1 0.1016/j.compedu.2018.07.003.

43. Liu Y-O, Li Y-F, Lei M-J, Liu P-X, Theobald J, Meng L-N, et al. Effectiveness of the flipped classroom on the development of self-directed learning in nursing education: a meta-analysis. Front Nurs. 2018;5(4):317-29. https://doi. org/10.1515/fon-2018-0032.

44. Bognar B, Sablić M, Škugor A. Flipped learning and online discussion in higher education teaching. Didactics Smart Pedagog. 2019:371-92. https:// doi.org/10.1007/978-3-030-01551-0_19.

45. Siqueira MAM, Gonçalves JP, Mendonça VS, Kobayasi R, Arantes-Costa FM, Tempski PZ, et al. Relationship between metacognitive awareness and motivation to learn in medical students. BMC Med Educ. 2020;20(1):1-10. https://doi.org/10.1186/s12909-020-02318-8.

46. Zamnah L, Ruswana A, editors. Implementation of a self-directed learning model to improve students' self-regulated learning and selfconfidence. J Phys. 2019. IOP Publishing. https://doi.org/10.1088/17426596/1188/1/012081.

47. Karatas K, Arpaci I. The role of self-directed learning, metacognition, and 21 st-century skills predicting the readiness for online learning. Contemp Educ Technol. 2021;13(3):ep300. https://doi.org/10.30935/cedtech/10786.

48. Adinda D, Mohib N. Teaching and instructional design approaches to enhance students' self-directed learning in blended learning environments. Electron J eLearn. 2020. https://doi.org/10.34190/EJEL.20.18.2.005.

49. Elfeky AIM, Masadeh TSY, Elbyaly MYH. Advance organizers in flipped classroom via e-learning management system and the promotion of 
integrated science process skills. Thinking Skills Creativity. 2020;35:100622. https://doi.org/10.1016/j.tsc.2019.100622.

50. Geng S, Law KM, Niu B. Investigating self-directed learning and technology readiness in blending learning environment. Int J Educ Technol High Educ. 2019;16(1):1-22. https://doi.org/10.1186/541239-019-0147-0.

51. Van Vliet EA, Winnips JC, Brouwer N. Flipped-class pedagogy enhances student metacognition and collaborative-learning strategies in higher education but effect does not persist. CBE_-Life Sci Educ. 2015;14(3):ar26. https://doi.org/10.1187/cbe.14-09-0141.

52. Yong D, Levy R, Lape N. Why no difference? A controlled flipped classroom study for an introductory differential equations course. Primus. 2015;25:90721. https://doi.org/10.1080/10511970.2015.1031307.

53. Chan CWH, Tang FWK, Chow KM, Wong CL. Enhancing generic capabilities and metacognitive awareness of first-year nursing students using active learning strategy. BMC Nurs. 2021;20(1):1-8. https://doi.org/10.1186/s12912021-00601-7.

54. Müller L-M, Goldenberg G. Education in times of crisis: effective approaches to distance learning. 2021.

55. Delle Site C. Investigating metacognition in new graduates transitioning to professional nursing practice. 2019.

56. Bektas I, Bektas M, Ayar D, Akdeniz Kudubes A, Sal S, Selekoglu OK Y, et al. The predict of metacognitive awareness of nursing students on selfconfidence and anxiety in clinical decision-making. Perspect Psychiatr Care. 2020. https://doi.org/10.1111/ppc.12609.

57. Örs M, Titrek O. The correlation between metacognitive awareness level and self-directed learning readiness of undergraduate nursing and midwifery students. J Educ Train Stud. 2018;6(11a):218-28. https://doi.org/10.11114/ jets.v6i11a.3819.

58. Arifani Y, Asari S, Anwar K, Budianto L. Individual or collaborative whatsapp learning? a flipped classroom model of EFL writing instruction. Teach Engl Technol. 2020;20(1):122-39.

59. Annamalai N. Using whatsapp to extend learning in a blended classroom environment. Teach Engl Technol. 2019;19(1):3-20.

60. Durgungoz A, Durgungoz FC. "We are much closer here": exploring the use of whatsapp as a learning environment in a secondary school mathematics class. Learn Environ Res. 2021:1-22. https://doi.org/10.1007/s10984-021-093 71-0.

\section{Publisher's Note}

Springer Nature remains neutral with regard to jurisdictional claims in published maps and institutional affiliations.

Ready to submit your research? Choose BMC and benefit from:

- fast, convenient online submission

- thorough peer review by experienced researchers in your field

- rapid publication on acceptance

- support for research data, including large and complex data types

- gold Open Access which fosters wider collaboration and increased citations

- maximum visibility for your research: over $100 \mathrm{M}$ website views per year

At $\mathrm{BMC}$, research is always in progress.

Learn more biomedcentral.com/submissions 